\title{
E-Learning Development for Special Education Postgraduate Students
}

\author{
https://doi.org/10.3991/ijet.v15i14.13893
}

\author{
Sri Joeda Andajani ${ }^{(凶)}$, Asri Wijiastuti \\ Universitas Negeri Surabaya, Surabaya, Indonesia \\ sriandajani@unesa.ac.id
}

\begin{abstract}
The specific purpose of this study is to report the process of developing e-learning course on motion-building and mobility for students' learning at the postgraduate of special education study program. This research was conducted to measure the e-learning capability on motion-building and mobility courses, which were applied through expert validation tests by using instruments in conducting assessments. Whereas the test users are the postgraduate students of special education study program by using the instrument in conducting assessment. The blended learning model of motion-building and mobility courses is designed and packaged offline in online textbooks of motion-building for blind children and motion theraphy of cerebral palsy children. Based on the process of assessing the feasibility of the product's validity and practicality, the product validity test results from the validator on all assessment items get a good result in score 3.6. The assessment results to test the practicality of users toward the product obtain a good result in score 3.4. Based on those results, it can be concluded that the implementation of e-learning on movement and mobility course for learning in postgraduate of special education study program worthiness is proven.
\end{abstract}

Keywords-Development, e-learning, postgraduate, special education

\section{$1 \quad$ Introduction}

National Education Standards in Indonesia is that the learning process in the education unit is held interactively, inspiratively, fun, challenging, motivating students to participate actively, as well as providing sufficient space for initiative, creativity and independence in accordance with the syudents' talents, interests, physical and psychological development. The realization is one form of inspiration in how to develop teaching materials on motion-building and mobility course. The learning innovation is the demand of conventional nature that is integrated with information and communication technology according to the demands of the digital era [1-6].

The instruments design that can be visualized and audio-packed is packaged through the empowerment of learning resources based on information and communication technology (ICT) [7-13]. Therefore, the development of instructional materials for motion-building and mobility was deliberately chosen in the lecture of special 
education study program, because they are unique to the target of children with special needs and their various characteristics. Another advantage is that between the physically disable, cerebral palsy and the visually impaired in motion-building and mobility have differences, especially in providing learning services for each child. Therefore, the development of this teaching material for ICT packaging for lectures requires a learning program by combining the advantages of face-to-face learning, and e-learning offline-online. This means that educators in the class have the potential to operationalize information and communication technology (ICT) equipment as a learning source for postgraduate of special education students.

The findings about blended learning can shift the conventional learning paradigm toward information and communication technology in developing new knowledge, skills, and behaviors for students [14-23]. In blended learning as a process, teaching and learning activities require a variety of methods, models and learning medias that are applied to achieve maximum results and quality [24-28]. The results of preliminery research emphasizes that classroom learnings which use information and communication technology with media packaging that can be visualized and audio visualized inspire, motivate, challenge and please the acquisition of effective learning behaviors for students. On the other side of Motion-building and mobility learning course, facilities to support online procurement at Surabaya state universities have been developed, but the implementation is still not optimal. The delivered learning especifically in the Department of Special Education still tends to use conventional learning media such as taking notes from the blackboard and power point presentation software media. This means that in the study of the information and communication technology usage such as the blended learning model has not yet been realized effectively and interactively when conducting learning in the classroom.

Specifically, in the course of Motion-building and mobility as a foundation in the special education study program requires an understanding that is not only focused on the form of learning that still uses power point exposure, still images (nonmultimedia) and translation book reference. In the other side, the motion-building and mobility course is largely a subject that requires a comprehensive picture of the various disabilities conditions that have different characteristics and needs in the motionbuilding and mobility services. However, the presented learning material in the learning process for now tends to be conventional with oral, discussion of the translation results, so it is less effective in exploring or understanding the material when it is described by using power point media for students.

The other side of the motion-building and mobility course material is sought to be more applicable according to field conditions that is intended for children with cerebral palsy, visual impairment, autism, and so on. The packaging of teaching materials based on blended learning for the subject of motion-building and mobility development has made postgraduate students of special education study programs inspired in developing more widely through the thesis concept. 


\subsection{Problem formulation}

Based on the description, the problems in the implementation of the blended learning model on motion-building and mobility courses for postgraduate students in special education program can be formulated as follows:

1. How is the validity of the product in the implementation of blended learning model on motion-building and mobility course for postgraduate students of special education Study Program in Surabaya State University?

2. How is the practicallity of the product in the implementation of blended learning model on motion-building and mobility course for postgraduate students of special education Study Program in Surabaya State University?

\section{Literature Review}

\section{$2.1 \quad$ E-Learning: Blended learning model with offline dan online basis}

Blended learning is basically a combination of learning excellence that is done face-to-face and virtually [29-33]. Blended learning is defined as mixing between online and face-to-face meetings in one integrated learning activity in a pedagogical environment [34-36]. Therefore, the Blended learning model is a used conceptual as a guideline in conducting activities that refer to learning that combines or mix face-toface learning and computer-based learning (online and offline).

The "e-learning model", online internet is one of the programs that utilize computer media [37-38]. The functions of e-learning to learning activities in the classroom are:

- Supplement for students to have additional knowledge or broaden their knowledge

- Complement or that the meaning of e-learning material is programmed to become enrichment or remedial for students in following conventional learning activities

- Substitute for e-learning as an alternative learning teaching material [39-43]

E-learning allows students to gain knowledge without having to attend classes physically, delivered by using electronic media connected to the internet (world, wide, web / www that connects all computer units thatare connected to the internet) and the internet (a network that can connect all computer units in a limited certain environment). Learners by using e-learning are divided into three types, namely: Text and Graphics Web-based Learning, Interactive Web-based Learning, Inter-active Multimedia Web-based Learning. To implement e-learning online, there are three components as a minimum for forming e-learning programs, namely: e-learning infrastructure, e-learning systems, and e-learning content. 


\section{$2.2 \quad$ E-Learning based learning material}

The development of teaching materials for the use of the web for learning into three groups, they are web courses, web centric courses, and web enhanced courses $[6,44]$. In using e-learning, they optimize their visual abilities in operating their learning activities as a classification of visual learning styles. Therefore, in learning interactions, approaches and media used can be more easily understood if the learning material is packaged visually. Thus, the learning process of students needs to be given e-learning learning methods in order to enrich and explore the mastery of learning material by utilizing various available sites on the internet.

\subsection{Learning material of motion-building and mobility}

Motion-building is development and training in developing knowledge, skills and attitudes for students who experience motor disturbances to foster their movements in carrying out activities of daily living. For the visually impaired, mobility includes the acquisition of skills and techniques that make people with visual impairments can travel and perform daily activities more easily in their environment [45-48]. For people with physical disabilities both physically impaired, cerebral palsy and visually impaired the motion-building and mobility are needed in daily life for their activities [45-53]. In addition, the characteristics of each disability are different, so that providing services and coaching is depending on the level of need. The teaching or learning material is one of the most important elements and must be available for teaching and learning activities. So, teaching materials need to be arranged systematically so that students can learn independently and are designed according to the applicable curriculum. With the existence of teaching materials, educators can be more coherent in teaching material to students so that it is easier to accept the taught material.

\subsection{The linkages between blended learning model of buiding motion and mobility courses}

The best student learning is arranged systematically to inspire, to be fun and motivate, so that they can learn independently and are designed according to their grade or level. Then specifically learning is centered on what, how and where that suits the needs of the students. In learning that suits the needs of postgraduate students is about what is taught. Principles of learning methods in the context of how learning is provided and, finally, a learning place that suits the needs of the postgraduate students where learning needs to be given a blended learning model that can enrich and explore the mastery of learning material both offline and utilizing various available site on the internet. The development of instructional materials for motion-building and mobility based on blended learning use the principles of the following learning methods.

- The learning is in accordance with the learning needs of students.

- Educators emphasize learning through visual channels both offline and online. 
- The learning requires real experience in learning the concepts of subject matter.

The linkages of motion-building and mobility instructional materials based on blended learning are prioritized in the way of the learning products packaging that is delivered to postgraduate students of special education study program so they comprehensively understand the teaching materials. The complexity of the characteristics and needs of children with special needs will be serviced and fostered through their movements and mobility so that they can participate and socialize with their environment, the blended learning model as an alternative to develop teaching materials both offline and online.

\section{$3 \quad$ Research Methods}

\subsection{Type of reseach}

Research and development (R\&D) approach is used in this research. Product development is not only in the form of learning media, but can be in the form of procedures, instruments and learning processes, as well as producing model products. The used stages in the implementation of the Blended Learning model on motion-building and mobility course is adapting the development model Gall, Gall and Borg [54] for learning in the form of offline and online, namely 1) expert validity test, 2) revision of expert test results, 3) small-scale trials, and 4) revisions of the trial results and as the final product of the model. The election of the development model [54] on the implementation of the Blended Learning model on motion-building and mobility course is with the following considerations.

- This development model begins with gathering information about implementing blended learning models in the bulding motion and mobility course. Likewise, it also starts with observation and interviews and needs assessment to find out the need for a blended learning model on motion-building and mobility course for postgraduate students of special education study program;

- This development model is simple and flexible, because it is very compatible with the goal of the blended learning model development on motion-building and mobility course, which is not complicated;

- The development phase in this model is a field test and product revision. Through repeated assessment and revision of product development, it can produce effective products. In addition, this development strategy was chosen because it consists of clear, detail, and systematic development implementation steps.

\subsection{Development procedures}

The procedure of implementing the Blended Learning model on motion-building and mobility subject for postgraduate students of special education study program is carried out in three stages. 
- Development preparation stage, which is to carry out need assessment, interviews and observations to determine the problem of the Blended Learning model of the motion-building and mobility courses for postgraduate students of special education study program;

- The stage of activity development that is carried out, namely formulating general goals, special objectives, and developing a blended learning model on motionbuilding and mobility courses for postgraduate students of special education study program. In developing measurement tools of blended learning model on motionbuilding and mobility courses for postgraduate students of special education study program which consist of: (a) Textbooks of motion-building and Mobilitycourse; (b) E-material of various services for cerebral palsy children and blind children.

- Product testing and evaluation stage, which includes the content expert responses and the design expert responses of the blended learning model in the motionbuilding and mobility courses for postgraduate students of special education study program.

Below is the description of development model [54] for the implementation of the Blended Learning model on motion-building and mobility course is as follows.

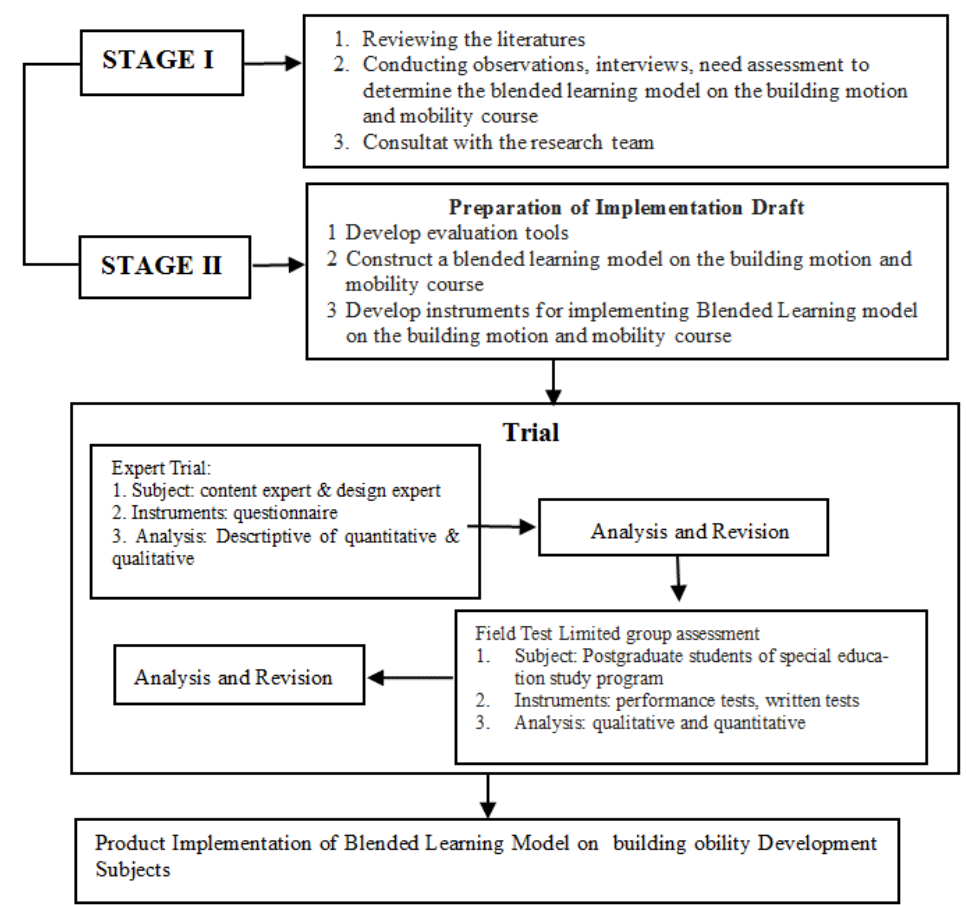

Fig. 1. Flowchart of the blended learning model implementation on the motion-building and mobility subject for special education postgraduate students 


\subsection{Product trial}

Product trials are conducted to obtain data in the form of suggestions, responses, and criticisms from experts and prospective users that can be used as a basis for improving the product development result. The product development trial of blended learning-based motion-building and mobility for postgraduate students of special education study program in Surabaya State University was carried out in two stages, namely the responses of content experts and design experts, and prospective users. In the blended learning model on motion-building and mobility courses for postgraduate students of the special education study program in Surabaya State University, the design of the product trial is based on the responses and suggestions of content experts and design experts, and prospective users can be seen in Figure 2. Subjects of the blended learning model product trial on on motion-building and mobility courses for postgraduate students of the special education study program in Surabaya State University.

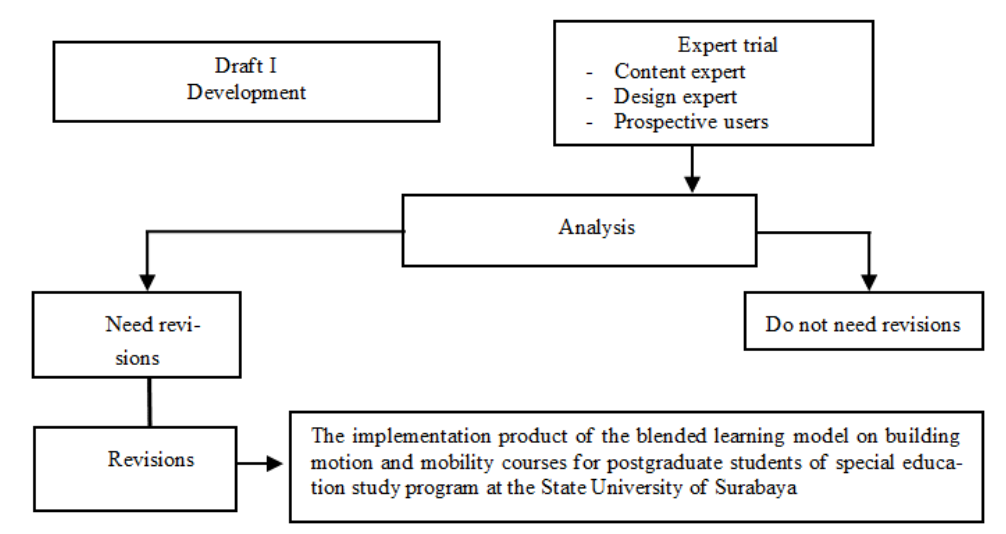

Fig. 2. Product Trial Design Based on Content Expert Response and Design Expert, and Prospective Users

\subsection{Data collection instrument}

Data collection instruments at the stage of the blended learning model on motionbuilding and mobility courses for postgraduate students of special education study program at the Surabaya State University were conducted by using an assessment questionnaire. The questionnaire was developed (valid and reliable) to collect expert opinions on the feasibility of the blended learning model on motion-building and mobility courses for postgraduate students of special education study program at the Surabaya State University. Content and design experts were asked to rate the development level of model from three aspects:

- Uses: The blended learning model on motion-building and mobility courses for postgraduate students of special education study program at the Surabaya State 
University refers to the acquisition of the model development results that can provide benefits for postgraduate students of special education study program. The development usefulness indicators of the motion-building and mobility courses for postgraduate students of special education study program at the Surabaya State University are first, users. Referring to the benefits, the importance and advantages for postgraduate students of special education study program. Second, the needed skills. Referring to technical competence of the blended learning model on motionbuilding and mobility courses for postgraduate students of special education study program at the Surabaya State University. Third, the impact of using the blended learning model on motion-building and mobility courses for postgraduate students of special education study program at the Surabaya State University.

- Appropriateness: to find out how big the practicality and effectiveness of the blended learning model on motion-building and mobility courses for postgraduate students of special education study program at the Surabaya State University. As for the indicators that show first, the practicality of this procedure refers to the ease of implementing technical learning. Second, the effectiveness of cost, time, and energy. This indicator refers to the comparison of the acquisition of expert test results.

- Accuracy: This blended learning model on motion-building and mobility courses for postgraduate students of special education study program at the Surabaya State University refers to the acquisition of response results and the advice of media experts, special education experts and users who can meet the understanding target of teaching material in postgraduate students of special education study program.

\subsection{Data analysis technique}

In obtaining results is quantitative data, so it is analyzed in quantitative descriptive. Quantitative data were obtained from expert tests and user tests. The used criteria are in the assessments that are given by experts and users by providing questionnaires. The obtained data from expert and user evaluation questionnaires were classified in 4 answer categories (grades 1, 2, 3, and 4) and then converted as percentages. Based on expert assessments and small-scale field trials of the blended learning model components, the development components that receive assessments 1 and 2, have criteria to be revised. Because it shows the quality of the component is less feasible and needs to be revised. While the datas that are obtained from interviews, responses, suggestions, criticisms from experts and prospective users are arranged and grouped according to the assessed aspects. The data is used as the basis for improving the product effectiveness component of the blended learning model on motion-building and mobility courses at Surabaya State University.

\section{$4 \quad$ Results and Discussion}

In producing a product prototype for the development of blended learning-based motion-building and mobility learning materials for postgraduate students of special 
education study program at the Surabaya State University can go through stages or development processes. The carried-out development stages or process requires conformity with the existence rules of the theory and field conditions. The linkages of the stages or the development process are carried out correctly, and then a good blended learning model or representative product is produced according to the needs of the target audience, namely postgraduate students of special education study program.

The effectiveness stages of the blended learning model on motion-building and mobility courses for postgraduate students is as the initial stage for analysing the reference books and special field findings at the Foundation for Children with Disabilities and the Foundation for Children with Blindness. This analysis is carried out as a step for the product manufacture of blended learning model on motion-building and mobility courses. The stage of the implemention process of the blended learning model on motion-building and mobility courses for postgraduate students, referring to the research development model of Gall, Gall and Borg [54]. Some steps or cycles are carried out at the stage of the implementation process of the blended learning model on motion-building and mobility courses for postgraduate students as follows.

\subsection{Research and information collection}

Analyzing to get theoretical references and field findings: This analysis stage is a preliminary implementation for the search and collection of the developed information through analysis to obtain theoretical references and field findings that is exist in orthopedically handicapped special school blind special school for the implementation of the blended learning model of motion-building and mobility courses. This analyzing activity is carried out with reference studies from various kinds of learning initiation that have been carried out by lecturers of motion-building and mobility in the postgraduate of special education postgraduate study program in carrying out the process of class lectures, among them.

- The availability of foreign language teaching materials (English) in the form of Handbooks is used in conducting lectures, but has not been designed to be used as a book to facilitate students' understanding.

- Demands for lecture needs that are designed through e-learning programs in the motion-building and mobility course that are are easy to be used for postgraduate students of special education courses have not exist yet.

- Learning in a number of studying materials for the course of motion-building and mobility has not been designed for students, so that it can facilitate learning independently and practically both offline and online that can be studied anywhere and anytime.

- Availability of teaching materials that are packaged in a blended learning model has not exist yet in the postgraduate od special education study program.

Analyzing the competency structure in the course, so that it is connected in the prerequisite, procedural, grouping or combination structure: The course of motionbuildingand mobility is in accordance with its learning achievements that utilizes 
science and technology to obtain references from various sources about the concepts of motion-building and mobility, principles, theories, types of motion development, principles and service methods of motion exercises for limbs. Because of this, postgraduate students in special education study program are able to master the concepts of theory, principles and apply courses on motion-building mobility and mobility for the development of science and technology that produces innovative work that can be packaged through scientific work on the thesis theme. Then in this course, postgraduate students of special education study program through an inter / multidisciplinary approach are able to help solveing problems for children with special needs of the blind and physically impaired and cerebral palsy children.

Analyzing alternative competency structures in the motion-building and mobility courses in entry behavior that can be obtained by students: After the postgraduate students of special education study program have the potential to take responsibility for the learning performance individually and in groups, by showing active involvement in carrying out the tasks and roles during the learning process. As well as utilizing learning resources and ICTs to support the implementation of learning. Therefore, this course on the motion-building and mobility is packaged through a blended learning model both offline and online. The other side of this course has not been packaged so that students can easily learn independently and practically.

\subsection{Planning}

This motion-building and mobility lecture material is packaged through a blended learning model that is designed to teach postgraduate students, so that the competency in the indicators is adjusted based on facts, concepts, principles and procedures on which the basic material has been determined. Based on the results of the courses existence review in the second semester, they have not yet resolved certain problems regarding learning of moton building and mobility in the field of special education in serving the blind who need mobility. In addition, motion-building services for the orthopedically handicapped and cerebral palsy are all different. Below is the preparation of teaching materials based on blend-ed learning begins with defining.

Defining the learning objects at each level: The selection of motion-building and mobility course materials is adjusted to the content that is packaged via offline and online. This teaching material consists of the structure and function of joints, shoulder joints, elbows, wrists \& hands, spine, groin, knee joints, ankles and feet by using online packaging in a virtual learning program. Then the learning material is packaged in offline, namely the concept of building motion and mobility, a brief history of exercise physiology, kinesiology, tactical and haptic perception, mobility devices, psychosocial dimensions, methods for anaerobic exercise and physiological responses, physical and health activities, training for people with disabilities, and temperature setting exercise in cool and hot places.

Defining the prerequisites and competencies of each learning object: The understanding of postgraduate students of special education study programs in learning achievement has the potential to utilize science and technology, master, make decisions about concepts and theories within the scope of motion-building and mobility, 
as well as being responsible for individual and group learning performance. This means that the design in this course is for postgraduate students to have an active involvement in carrying out the assignments and roles individually or in groups throughout the learning process, as well as utilizing learning resources and ICTs to support learning.

Defining the relation of each learning object: The achievement of motionbuilding and mobility courses for the design of teaching materials between offline and online has a mutual collaboration. Materials that are related to body service exercises, joint structure and function, shoulder joints, elbows, wrists \& hands, back groin, groin, knee joints, ankles and legs, nervous \& motor system, games, mobility, is trained by using the tools are packaged through an online program. Whereas those that are packaged offline, is the concept of motion- building and mobility, a brief history of exercise physiology, kinesiology, tactical and haptic perception, mobility devices, psychosocial dimensions, methods for anaerobic exercise and physiological responses, physical and health activities, training for training for people with disabilities, and temperature setting exercise in cool and hot places. This shows that the packaging of the designed materials both offline and online are interconnected to be used as student assignments.

Designing the learning object metadata: This learning object metadata is classified through material about a) introduction of the motion and mobility services program is carried out by people who have competencies in their fields, such as handling children with cerebral palsy who have various types of disorder by using audio visual programs that are packaged with manufacturing learning videos, b) the introduction of early motion-building for blind children before being able to be oriented and mobility, is introduced to various movements through an audio visual program that is packaged with the making of learning videos, c) the introduction of occupational therapy for cerebral palsy children is also conceptualized through an audio visual program thatis packed with learning videos, and d) concepts, principles, theories, and types of motion- building and mobility, is packaged through book as teaching material.

\subsection{Develop preliminary form of product}

At this stage, developing the product prototype of the blended learning model for motion-building and mobility courses, is through the steps of:

- Determining the prototype design of the blended learning model for motionbuilding and mobility courses

- Determine the content of the material for teaching in the form of learning books and videos

- Making learning video scripts and book forms for teaching materials

- Validation instruments. The design of the initial product prototype development of the blended learning model for motion-building and mobility courses is as follows.

Determining the prototype design of the blended learning model for motionbuilding and mobility course product: The initial step of making the blended learn- 
ing model for motion-building and mobility for special education study program students is by arranging systematic teaching materials. The results of the study of various book references and translation are taken into consideration to determine the design of the product model of the blended learning model for motion-building and mobility. Then with consideration together with learning media experts, designing videos for material dealing with motor or motion disorders in cerebral palsy children and understanding the basic motion for the visually impaired. The basis is to create a learning video program as a step to determine the Blended Learning modification program of motion-building and mobility for special education study program for the manufacture of permanent products for future learning initiatives.

Determining the material content for teaching materials in the form of books and learning videos: After determining the software program, the next step is to determine the type of the used hardware and software to create a blended learning model on motion-building and mobility. Determine and assemble software programs that require internet assistance to create audiovisual learning programs. In making the audiovisual program which will be positioned on the virtual learning as a direction of learning independence that can be used by postgraduate students of the special education program.

The designing of this motion-building and mobility teaching material is as a learning object strategy for postgraduate students of special education who use blended learning model both offline and online. This offline learning object strategy is designed in the form of a textbook for motion-building and mobility, along with the cover and table of contents below. Then, learning by using the blended learning mod$\mathrm{el}$ as a form of independent learning without face to face with the lecturer is as one of the academic standards for postgraduate students of special education study program at the Surabaya State University. The packaging of e-material in this e-learning standard specification is an alternative that postgraduate student does not have to be faceto-face but can be facilitated by provided technology. Therefore, the facilities that have been provided by Surabaya State University require innovation of lecturers in postgraduate courses. Below is video material that is packaged through a compact disk for motion therapy learning for children with cerebral palsy and basic motion for blind children

While the online system is designed to be an audiovisual program by packaging elearning / virtual learning media whose content and teaching material is in the form of multimedia-based content. The material for motion-building and mobility in the material of structure and function of joints, shoulder joints, elbows, wrists \& hands, spine, groin, knee joints, ankles and feet is designed by using e-learning / virtual learning media. The design of the content and teaching materials in the mentioned material above is packaged in the form of multimedia-based content (multimedia-shaped content), in order to facilitate students to understand knowledge and be able to respond to the meaning of the material. The design for the course of motion-building and mobility in postgraduate students of the special education study program refers to the learning achievements of utilizing science and technology, mastering theoretical concepts, principles and applying movement and mobility development, making decisions and 
being responsible for individual and group learning performance by showing active involvement in carrying out their duties and roles.

Develop e-material by applying OP reuse and repurpose at each level, as well as reuse and repurpose information objects and digital assets (identifying new content and existing content). The material on the course of motion-building and mobility is classified into 2, namely offline and online forms. Specifically, e-material online prioritizes material that cannot be read only, but through practice. The use of media is as a learning model that has been packaged through an audiovisual program that is developed in e-material. Virtual learning program has been prepared by Surabaya State University as a place to develop e-material specifically on the material structure and function of joints, shoulder joints, elbows, wrists \& hands, spine, groin, knee joints, ankles and feet pre-packaged through an audiovisual program.

Develop e-material by using technology that is device independent. Material structure and function of the joints, shoulder joints, elbows, wrists \& hands, spine, groin, knee joints, ankles and feet cannot be read by understanding, but requires the form of modeling examples through a variety of correct stages. The e-material development is a place that is packaged in a compact disk that is representative for storage of virtual learning programs that have been prepared by Surabaya State University. The ematerial package follows the e-learning standard specifications.

- The selection of motion-building and mobility course materials are adjusted to the content that is packaged through offline and online. This teaching material consists of the structure and function of joints, shoulder joints, elbows, wrists \& hands, spine, groin, knee joints, ankles and feet by using online packaging in a virtual learning program. Then the learning material that is packaged in offline is the concept of building mobility and mobility, a brief history of exercise physiology, kinesiology, tactical perception and haptic perception, mobility devices, psychosocial dimensions, methods for anaerobic exercise and physiological responses, physical activity and health, Training for people with limited mobility, and temperature control training in cold and hot places.

- Understanding of postgraduate students in special education study programs in learning achievements has the potential to utilize science and technology, master, make decisions about concepts and theories within the scope of motion-buildig and mobility, as well as take responsibility for learning performance individually or in groups. This means that the design in this course is for postgraduate students to have an active involvement in carrying out the tasks and roles given both individually and in groups during the learning process, as well as utilizing learning resources and ICTs to support the implementation of learning.

- In the achievement of motion-building and mobility courses, the design of teaching materials on between offline and online have a mutually collaborative relationship. Material related to body service exercises, joint structures and functions, shoulder joints, elbows, wrists \& hands, spine, groin, knee joints, ankles and feet, nervous \& motor system, games, mobility, use assistive devices package through an online program. Whereas the ones that are packaged offline are the concept of body building and mobility, a brief history of exercise physiology, kinesiology, tactical and 
haptic perception, mobility devices, psychosocial dimensions, methods for anaerobic exercise and physiological responses, physical and health activities, training for people with movement limitations, and temperature settings exercise in cold and hot places. This shows that the packaging of materials that are designed both offline and online are interconnected to be used as student assignments.

- This learning object metadata is classified through material about a) introduction of the motion and mobility services program is carried out by people who have competencies in their fields, such as handling children with cerebral palsy who have various types of disorder by using audio visual programs that are packaged with manufacturing learning videos, b) the introduction of early motion-building for blind children before being able to be oriented and mobility, is introduced to various movements through an audio visual program that is packaged with the making of learning videos, c) the introduction of occupational therapy for cerebral palsy children is also conceptualized through an audio visual program thatis packed with learning videos, and d) concepts, principles, theories, and types of motion- building and mobility, is packaged through book as teaching material.

- In designing instructional materials for the learning object pursuance on motionbuilding and mobility by using blended learning both offline and online, this offline learning object strategy was designed in the form of textbooks for motionbuilding and mobility.

Based on the implementation of the blended learning model on motion-building and mobility learning courses for the postgraduate students of special education study program, the mainstreaming is on the utilization of information and communication technology with internet packaging or online e-learning which has been facilitated by the Surabaya State University. Aside from being part of an effort to improve the learning outcomes of postgraduate students of special education study program, it plays an important role in preparing competitive qualification standards for graduates in the community. Another urgency in the current development of the internet usage for educational purposes is increasingly widespread, especially in developed countries. The fact of the findings shows that online media enables more effective teaching and learning process. Furthermore, independent learning through E-learning provides opportunities for students to take control of the learning success for each other. This means that learners are given the freedom to determine when they will start, when they will finish and what parts of the material they want to learn first. Learners start from topics or pages that attract interest first or can just pass through the parts that are considered to have been mastered. If someone have difficulty to understand particular part you can repeat it again until it is understood. If after repeating there are still things that are not understood, students can contact the instructor / resource via e-mail or interactive dialogue at certain times. E-learning, learners and students can communicate easily through regular internet facilities or whenever the communication activities are carried out without being limited by time and place [55-58]. Learners and students can use instructional materials or instructional learning that is structured internet. The independence of learning with e-learning programs requires students to learn independently and autonomously [39-41]. 
Regarding the method of blended learning education, the relationship among learners is closely a central point of education [32-36]. This method can produce good quality education, and not only make students smart but also educated with polite behavior. Furthermore, the impact of the infrastructure conditions and learners is not appropriate, and the more the number of students, the conventional method will not achieve maximum results. The results of learning research that integrates learning by using computers (internet) with traditional methods states that, achievements are better with computers (internet) [59-63]. Learning is best for students if it is arranged systematically which could inspire, be fun and motivate, so that they can learn independently and are designed according to their grade or level. Specifically learning is centered on what, how and where that suits the needs of Surabaya State University graduate students being facilitated. In learning, thing that suits the needs of students in the bachelor degree is about what is taught. The principles of learning methods is the context of how learning is provided and the last place of learning that suits the needs of postgraduate students where learning needs to be given a blended learning method that can enrich and explore the mastery of learning material both offline and utilizing various site available on the internet. In developing instructional materials for motionbuilding and mobility based on blended learning by using the principles of learning methods:

- Learning is in accordance with the learning needs of postgraduate students of special education study programs

- Educators emphasize learning through visual channels both offline and online

- Learning requires real experience in learning the concepts of subject matter

The interrelation of the blended learning model in the instructional materials for motion-building and mobility is prioritized in the way of learning products packaging delivered to postgraduate students of special education Study Program is comprehensively understanding teaching materials. The complexity of the characteristics and needs of children with special needs who will be served and fostered through their movements and mobility so that they can participate and socialize with their environment, the blended learning model as an alternative to develop teaching materials both offline and online.

\section{$5 \quad$ Preliminary Field Testing}

The product of the blended learning model on motion-building and mobility course for postgraduate students in the special education study program was conducted by a validation test by learning media experts, and practicality test by the postgraduate students in the special education study program users. This activity is to get an assessment and input as a basis for product revision. This validation and practicality test is an assessment step for the product of the blended learning model on motionbuilding and mobility course that has been developed. This step aims to obtain an assessment of the appropriateness of the blended learning model on motion-building and mobility course for postgraduate students in the special education study program. 
Mainstreaming is done before the blended learning model on motion-building and mobility course was tested on postgraduate students in the special education study program who programed the course. The foundations for obtaining the validation of eligibility from expert validation and user validation are urgently needed as an appraisal test of product competency that is appropriate to be used. Therefore, with the blended learning model on motion-building and mobility course, the feasibility was tested on the experts and users, the research team held a meeting by joining discussion between the research team from special education education study program, learning media, and postgraduate students in the special education study program as users.

As for the implementation results of the of this focused group discussion, the acquisition of the undestanding contains:

- Determination of validators from the field of learning media

- Displaying therapeutic learning video "Cerebral Palsy Child's Motion and Basic Blindness Childhood Learning"

- Users provide input results of the impressions one by one

- Learning media validators provide input results of the shows one by one

- Submit instruments and fill out media and user validators

Along with assessing the feasibility of the product, the media validator and the user have prepared an instrument in the form of a questionnaire. The task of the validator and the user is to provide an assessment through the answers to a series of statements that exist and provide input in the form of criticism and suggestions on the provided sheet. One expert acts as a validator and two people as users (2 students).

\subsection{Learning media validators and special education}

The appointed learning media validator and special education scientific field to validate. The task is to conduct verification of the blended learning model of the motionbuilding and mobility course that has been developed in textbooks and learning videos. Expert assessment of the motion-building and mobility course product is in line with the clarity of the scenario components as a series of syntax systems in the blended learning model on motion-building and mobility course. The use of shooting tools series with the strength of information technology and communication as well as the clarity of the final results contained in the blended learning model on motion-building and mobility course is used for postgraduate students in special education study program. Below are the results of input from the validator in a qualitative description:

- Improve the appearance of images in the learning video that have no connection with motion therapy

- In textbooks, correct incomplete word errors

- Book covers are given the bright names of each composing.

The linkage of the assessment analysis from the validator to all assessment items received a score of 3.5 and then it was converted to a validity level table, showing that the results of the feasibility of the validator (the field of learning media and special 
education) got good results. This means that the blended learning model on motionbuilding and mobility course for the learning of postgraduate students at special education Program of Surabaya State University is feasible to be used in the field.

\subsection{User}

The relevance of this practicality test was appointed and at the same time as a user was two special education postgraduated students. The task is to evaluate the appropriateness of the blended learning model on motion-building and mobility course with the content of the course description in learning lecture understanding. Practical assessment of blended learning model on motion-building and mobility course by using the appropriate description of the course both offline and online as an understanding of postgraduate students of special education study program. Then the clarity of the book and the accuracy of systematic indicators as guidelines and learning strangeness are learned by the postgraduate students of special education study program as users. Regarding the product of the blended learning model on motion-building and mobility course, it can be viewed from the level of service that can be used by the user. Below are the results of input from users in a qualitative description that needs to be corrected to be the same as those delivered by the learning media and special education validator on the blended learning model on motion-building and mobility course from users:

- Improve the appearance of images in the learning video that have no connection with motion therapy

- In textbooks, correct incomplete word errors

- Book covers are given the bright names of each composer

The linkage of the data analysis of the users' assessment to all assessment items get a score of 3.4 and then it is converted to a validity level table, showing that the feasibility results of users (graduates and undergraduate students of special educaton study program) got good results. This means that the blended learning model on motionbuilding and mobility course for the learning of postgraduate students of special education study program Surabaya State University is suitable to be used in lectures. Specifically designed learning meets the criteria of valid, practical and effective can improve the learning outcomes of prospective teachers in higher education [64-68].

The product of the blended learning model on motion-building and mobility course for postgraduate students in the special education study program was conducted by a validation test by learning media experts, and practicality test by the postgraduate students in the special education study program users. This activity is to get an assessment and input as a basis for product revision. This validation and practicality test is an assessment step for the product of the blended learning model on motionbuilding and mobility course that has been developed. This step aims to obtain an assessment of the appropriateness of the blended learning model on motion-building and mobility course for postgraduate students in the special education study program.

Mainstreaming is done before the blended learning model on motion-building and mobility course was tested on postgraduate students in the special education study 
program who programed the course. The foundations for obtaining the validation of eligibility from expert validation and user validation are urgently needed as an appraisal test of product competency that is appropriate to be used. Therefore, with the blended learning model on motion-building and mobility course, the feasibility was tested on the experts and users, the research team held a meeting by joining discussion between the research team from special education education study program, learning media, and postgraduate students in the special education study program as users.

As for the implementation results of the of this focused group discussion, the acquisition of the undestanding contains:

- Determination of validators from the field of learning media

- Displaying therapeutic learning video "Cerebral Palsy Child's Motion and Basic Blindness Childhood Learning"

- Users provide input results of the impressions one by one

- Learning media validators provide input results of the shows one by one

- Submit instruments and fill out media and user validators

Along with assessing the feasibility of the product, the media validator and the user have prepared an instrument in the form of a questionnaire. The task of the validator and the user is to provide an assessment through the answers to a series of statements that exist and provide input in the form of criticism and suggestions on the provided sheet. The nature of education encourages and provides interactive learning, teaches to work together and participates in student learning with friends in each group [6970]. Likewise, the teacher is able to foster a sense of pleasure toward learning, create creativity, motivation in doing tasks and provide convenience for their students to understand learning.

\section{$6 \quad$ Main Product Revision}

After the blended learning model on motion-building and mobility course was tested by learning media and special education field experts as well as users of postgraduate students in the special education study program, the product received input in the form of suggestions. Therefore, the basic input and suggestions need to be revised into the developed product. Revisions to the initial product or draft I are based on ratings, comments, and suggestions from validators and users. The revised draft $\mathrm{I}$ is then reported back to the validator and the user to be seen the improvements results that have been made through discussion. The results of the revision on this draft I are called draft II, then the validator and the user correct it again. Based on the revised draft II, input and the validator through reassessment provided suggestions after making observations on the blended learning model on motion-building and mobility course.

The basis results of the validator correction toward of the learning media and special education field experts as well as the user, stated that the blended learning model on motion-building and mobility course for learning in postgraduate of the special education study program in the form of draft II as a final product is feasible and has 
been prepared to be used by postgraduate of the special education study program. The implementation realization of blended learning model on motion-building and mobility course for learning in the postgraduate of the special education study program will be in the even semester of 2019. This means that the analysis results indicate appropriate criteria, the blended learning model on motion-building and mobility course for learning is ready to be used by postgraduate students of the special education study program.

Table 1. The revision of blended learning model on motion-building and mobility course by learning media and special eduction expert and users

\begin{tabular}{|l|l|l|l|}
\hline \multicolumn{1}{|c|}{ Revision } & $\begin{array}{c}\text { Learning Media and } \\
\text { Special Eduction Expert }\end{array}$ & \multicolumn{1}{|c|}{ Users } & \multirow{2}{*}{ Draft I } \\
\cline { 2 - 3 } & \multicolumn{1}{|c|}{ Draft I } \\
\hline $\begin{array}{l}\text { Correct the appearance of } \\
\text { images in the learning } \\
\text { video that have nothing to } \\
\text { do with motion therapy }\end{array}$ & $\begin{array}{l}\text { There is an improved image } \\
\text { on the learning video that } \\
\text { has nothing to do with } \\
\text { motion therapy }\end{array}$ & $\begin{array}{l}\text { There is an improved image } \\
\text { on the learning video that } \\
\text { has nothing to do with } \\
\text { motion therapy }\end{array}$ & $\begin{array}{l}\text { Has been fixed } \\
\text { according to input } \\
\text { from the validator } \\
\text { and the users }\end{array}$ \\
\hline $\begin{array}{l}\text { In textbooks, correct } \\
\text { incomplete word errors }\end{array}$ & $\begin{array}{l}\text { There are improvements to } \\
\text { the lacking writings in } \\
\text { textbooks }\end{array}$ & $\begin{array}{l}\text { There are improvements to } \\
\text { the lacking writings in } \\
\text { textbooks }\end{array}$ & \\
\hline $\begin{array}{l}\text { The book cover is given } \\
\text { the bright names of each } \\
\text { composing }\end{array}$ & $\begin{array}{l}\text { There is an improvement } \\
\text { with the addition of the } \\
\text { textbook compi-lers' name }\end{array}$ & $\begin{array}{l}\text { There is an improvement } \\
\text { with the addition of the } \\
\text { textbook compi-lers' name }\end{array}$ & \\
\hline
\end{tabular}

Apply technology to deliver material in various formats. One of the packaging is through compact disks for directed learning, so that students are able to process information into knowledge for courses on moton-building and mobility. The material is packaged through a compact disk with an audio-visual program in the form of instructional video media. This assessment stage is carried out at each of the above stages and functions like feedback to correct any possible errors that might occur. These sre the steps at this stage

- Learning object approach, feedback between fellow lecturers and students to reuse / repurpose learning objects. In the learning process, students are able to use knowledge to solve problems through materials that are delivered by lecturers by conducting feedback to measure the achievement of understanding teaching material.

- Evaluating learning objects. The blended learning model product is subject to an evaluation by using a validation test by learning technology experts, and special education experts. This activity is to get input as a basis for product revision. This validation test is a preliminary assessment of the developed product by the blended learning model. This step aims to obtain an assessment of the teaching availability and learning materials for motion-building and mobility courses by using blended learning.

After the blended learning model on motion-building and mobility course was tested on learning media and special education fied experts as well as users of postgraduate students of special education study program, the product received input in the 
form of suggestions. Therefore, the basic input and suggestions need to be revised to the developed product. This support is reinforced by another reseaarch that solving problem learning could train and develop the ability of students to solve an authentic problem from their actual life, to stimulate students' high-level thinking skills [71-75]. This means that the orientation model of social mobility and communication based on android applications has the potential to solve learning problems because it presents a process of introducing environment-oriented problems according to and can be found by students in real life. The validity test results of the product from the validator (learning media experts and special education experts) on all assessment items get a score of 3.6, which is good results score. Obtaining an assessment to test the practicality of the product users obtained a score of 3.4 , which is good results. Base on this, it can be concluded that the implementation of the blended learning model on motionbuilding and mobility courses for postgraduate students of special education in has proven its feasibility.

\section{Conclusion}

The implementation of the blended learning model of motion-building and mobility courses for postgraduate students of special education study Program has been designed based on the collaboration of instructional media experts and special education experts, as well as users' input. The process stages of the implementation results of the blended learning model of motion-building and mobility courses is through testing the feasibility of the validity and practicality of the product. The validity test results of the product from the validator (learning media experts and special education experts) to all assessment items get a score of 3.6 that is good score. The assessment to test the practicality of the product users obtained a score of 3.4, which is good results. Based on this, it can be concluded that the implementation of the blended learning model of motion-building and mobility courses for postgraduate students of special education has proven their feasibility. The product results development is the implementation of the blended learning model of motion-building and mobility courses for postgraduate students of special education at the Surabaya State University. Based on the above conclusions, the suggestions in this study are directed at the aspect of further development, as follows:

- Follow the expert validation test, as an effort to test the accuracy, and effectiveness of the of the blended learning model on motion-building and mobility course development for the learning of postgraduate students of special education study program

- Followed by making a prototype of the product in another course based on blended learning for postgraduate students in the special education study program. 


\section{Acknowledgements}

The author's gratitude goes to the State University of Surabaya for funding the Research (Grant Number: 802/UN38/ HK/PP/2019). Likewise, the author's gratitude goes to the Foundation for Children with Disabilities (YPAC) and the Foundation for Children with Blindness (YPAB) in Indonesia that have provided research.

\section{References}

[1] G. Pretto and G. Curró, "An approach for doctoral students conducting context-specific review of literature in IT, ICT, and educational technology," New Rev.Acad. Librariansh., vol. 23, no. 1, pp. 60-83, 2017. https://doi.org/10.1080/13614533.2016.1227861.

[2] F. Ozdamli, "Attitudes and opinions of special education candidate teachers regarding digital technology." World Journal on Educational Technology: Current Issues, 9 (4), 191-200, 2017. https://doi.org/10.18844/wjet.v9i4.2581.

[3] S. Salleh and K. Laxman, "Examining the Effect of External Factors and Context Dependent Beliefs of Teachers in the Use of ICT in Teaching: Using an Elaborated Theory of Planned Behavior," J. Educ. Technol. Syst., vol. 43, no. 3, pp. 289-319, 2015. https:// doi.org/10.1177/0047239515570578.

[4] A., Murugaiyan, \& S. Arulsamy, "Attitude of student teachers towards integration of assistive technology in inclusive classrooms". International Journal of Teacher Educational Research (IJTER), 2(4), 1-8, 2013.

[5] Alja'am, J. M., El-Seoud, S. A., \& Mwinyi, M. U. (2017). Design and Implementation of a Multimedia based Technology Solution to Assist Children with Intellectual Disability to Learn. International Journal of Emerging Technologies in Learning, 12(4). https://doi.org/ 10.3991/ijet.v12i04.6698.

[6] B. Asuman, M. S. H. Khan, and C. K. Clement, "Integration of Web-Based Learning into Higher Education Institutions in Uganda: Teachers' Perspectives," Int. J. Web-Based Learn. Teach. Technol. IJWLTT, vol. 13, no. 3, pp. 33-50, 2018. https://doi.org/10.4018/ ijwltt.2018070103.

[7] A. Saiger, "Homeschooling, virtual learning, and the eroding public/private binary," J. Sch. Choice, vol. 10, no. 3, pp. 297-319, 2016. https://doi.org/10.1080/15582159.2016. 1202070.

[8] Drigas, A., \& Kokkalia, G. ICTs and Special Education In Kindergarten. International Journal of Emerging Technologies in Learning, vol. 9, no. 4, pp. 35-42, 2018. https://doi. org/10.3991/ijet.v9i4.3662.

[9] J. Mbale, "African Youth Utilising IT-Essentials Innovation in Re-vitalisation of PCs to Equip Disadvantaged Rural Schools Shaping their ICT Learning Landscape: Namibian Case Study," International Journal of Emerging Technologies in Learning, vol. 9, no. 4, pp. 68-71, 2014. https://doi.org/10.3991/ijet.v9i4.3560.

[10] R. Hauser, R. Paul, and J. Bradley, "Computer self-efficacy, anxiety, and learning in online versus face to face medium," J. Inf. Technol. Educ. Res., vol. 11, pp. 141-154, 2012. https://doi.org/10.28945/1633.

[11] R. Stroud, B. Drayton, K. Hobbs, and J. Falk, "Interactive whiteboard use in high-tech science classrooms: Patterns of Integration,"International Journal of Emerging Technologies in Learning, vol. 9, no.9, pp. 41-49, 2014. https://doi.org/10.3991/ijet.v9i9.4141 
[12] Š. Bagon, M. Gačnik, and A. I. Starcic, "Information Communication Technology Use among Students in Inclusive Classrooms," International Journal of Emerging Technologies in Learning, vol. 13, no. 06, pp. 56-72, 2018. https://doi.org/10.3991/ijet.v13i06.805 $\underline{1}$

[13] Theodorou, P. and Drigas, A. S. (2017). ICTs and Music in Generic Learning Disabilities. International Journal of Emerging Technologies in Learning, vol. 12, no. 4, pp. 101-110. https://doi.org/10.3991/ijet.v12i04.6588

[14] J. E. Prescott, K. Bundschuh, E. R. Kazakoff, and P. Macaruso, "Elementary school-wide implementation of a blended learning program for reading intervention," J. Educ. Res., vol. 111, no. 4, pp. 497-506, 2018. https://doi.org/10.1080/00220671.2017.1302914

[15] D. Forbes, "Keynote: Going to university-Blended strategies for learning and teaching in a modern tertiary context," J. Open Flex. Distance Learn. vol. 20, no. 2, pp. 21-23, 2016.

[16] R. Schechter, P. Macaruso, E. R. Kazakoff, and E. Brooke, "Exploration of a blended learning approach to reading instruction for low SES students in early elementary grades," Comput. Sch., vol. 32, no. 3-4, pp. 183-200, 2015. https://doi.org/10.1080/073 $\underline{80569.2015 .1100652}$

[17] J. Loizzo and P. Lillard, "In the field: Increasing undergraduate students' awareness of Extension through a blended project-based multimedia production course," J. Ext., vol. 53, no. $1,2015$.

[18] K. Jusoff and R. Khodabandelou, "Preliminary study on the role of social pres-ence in blended learning environment in higher education.," Int. Educ. Stud., vol. 2, no. 4, pp. 7983, 2009.

[19] L. M. Jeffrey, J. Milne, G. Suddaby, and A. Higgins, "Blended learning: How teachers balance the blend of online and classroom components." J. Inf. Tech-nol. Educ., vol. 13, 2014. https://doi.org/10.28945/1968

[20] D. Levy, "Online, Blended and Technology-Enhanced Learning: Tools to Facilitate Community College Student Success in the Digitally-Driven Workplace.," Contemp. Issues Educ. Res., vol. 10, no.4, pp. 255-262, 2017. https://doi.org/10.19030/cier.v10i4.100 $\underline{39}$

[21] Y. Zhonggen, "Blended learning over two decades," in Professional Development and Workplace Learning: Concepts, Methodologies, Tools, and Applica-tions, IGI Global, 2016, pp. 1248-1267. https://doi.org/10.4018/978-1-4666-8632-8.ch068

[22] S. Gyamfi and P. Gyaase, "Students' perception of blended learning environ-ment: A case study of the University of Education, Winneba, Kumasi-Campus, Ghana," Int. J. Educ. Dev. Using ICT, vol. 11, no. 1, 2015.

[23] C. M. Tang and L. Y. Chaw, "Digital Literacy: A Prerequisite for Effective Learning in a Blended Learning Environment?” Electron. J. E-Learn., vol. 14, no. 1, pp. 54-65, 2016.

[24] O. Darojat, "Improving Curriculum through Blended Learning Pedagogy.," Turk. Online J. Distance Educ., vol. 17, no. 4, pp. 203-218, 2016. https://doi.org/10.17718/tojde.72654

[25] T. Szimkovics, "Blended Learning Opportunities in Ukrainian IT Public Educa-tion," Pract. Theory Syst. Educ., vol. 12, no. 2, pp. 60-70, 2018.

[26] C. C. Wai and E. L. K. Seng, "Measuring the effectiveness of blended learning environment: A case study in Malaysia," Educ. Inf. Technol., vol. 20, no. 3, pp. 429-443, 2015. https://doi.org/10.1007/s10639-013-9293-5

[27] N. Bakir, C. Devers, and B. Hug, "Affordances and constraints of a blended course in a teacher professional development program," J. Educ. Multimed. Hypermedia, vol. 25, no. 4, pp. 323-341, 2016. 
[28] M. Mohamad, H. Hussin, and S. Shaharuddin, "Adult Learners' Perceptions of Designed Hypermedia in a Blended Learning Course at a Public University in Malaysia.," Turk. Online J. Educ. Technol.-TOJET, vol. 14, no. 1, pp. 31-38, 2015.

[29] Y.-W. Lin, C.-L. Tseng, and P.-J. Chiang, "The Effect of Blended Learning in Mathematics Course.” Eurasia J. Math. Sci. Technol. Educ., vol. 13, no. 3, 2017.

[30] W.I. O’Byrne and K. E. Pytash, "Hybrid and blended learning," J. Adolesc. Adult Lit., vol. 59, no. 2, pp. 137-140, 2015. https://doi.org/10.1002/jaal.463

[31] A. Tzikopoulos, N. Manouselis, K. Kastrantas, and C. Costopoulou, "An online information system to support blended training of rural SMEs on e-government," Program, vol. 46, no. 1, pp. 123-143, 2012. https://doi.org/10.1108/00330331211204593

[32] J. M. Pima, M. Odetayo, R. Iqbal, and E. Sedoyeka, "A Thematic Review of Blended Learning in Higher Education,” Int. J. Mob. Blended Learn. IJMBL, vol. 10, no. 1, pp. 111, 2018. https://doi.org/10.4018/ijmbl.2018010101

[33] R. Owston, "Empowering Learners Through Blended Learning," Int. J. E-Learn., vol. 17, no. 1, pp. 65-83, 2018.

[34] R. Dwaik, A. Jweiless, and S. Shrouf, "Using Blended Learning to Enhance Student Learning in American Literature Courses." Turk. Online J. Educ. Technol.-TOJET, vol. 15, no. 2, pp. 126-137, 2016. [48] C. Ford, D. McNally, and K. Ford, "Using DesignBased Research in Higher Education Innovation.” Online Learn., vol. 21, no. 3, pp. 50-67, 2017. https://doi.org/10.24059/olj.v21i3.1232

[35] R. Austin, A. Rickard, and J. Reilly, "Face-to-face contact in blended learning for intercultural education: the role of teachers," Ir. Educ. Stud., vol. 36, no. 3, pp. 323-340, 2017. https://doi.org/10.1080/03323315.2017.1327364

[36] R. Austin, A. Rickard, and J. Reilly, "Face-to-face contact in blended learning for intercultural education: the role of teachers," Ir. Educ. Stud., vol. 36, no. 3, pp. 323-340, 2017. https://doi.org/10.1080/03323315.2017.1327364

[37] M. Al-Yahya, R. George, and A. Alfaries, "Ontologies in E-Learning: Review of the literature,” Int. J. Softw. Eng. its Appl., vol. 9, no. 2, pp. 67-84, 2015.

[38] C. Snae and M. Brückner, "Ontology-Driven E-Learning System Based on Roles and Activities for Thai Learning Environment," Interdiscip. J. e-Skills Lifelong Learn., vol. 3, pp. 001-017, 2007. https://doi.org/10.28945/382

[39] T C. Reeves and W. D. Aggen. Enhancing e-learning assessment and evaluation strategies. In Proceedings of ELEARN 2002 Vol. 2002 (1), 806811, 2002.

[40] R. Echeng and A. Usoro, "E-learning implementation issues and strategies to address low participation using an enhanced model of acceptance of web 2.0 technologies: A case study of a Scottish university," Int. J. E-Learn., vol. 16, no. 1, pp. 5-22, 2017.

[41] P. Arabasz and M. B. Baker, "Evolving campus support models for e-learning courses," Educ. Cent. Appl. Res. Bull., pp. 1-9, 2003.

[42] Ö. Özyurt and H. Özyurt, "Learning style based individualized adaptive e-learning environments: Content analysis of the articles published from 2005 to 2014," Comput. Human Behav., vol. 52, pp. 349-358, Nov. 2015. https://doi.org/10.1016/j.chb.2015.06.020

[43] S. R. Harandi, "Effects of e-learning on Students' Motivation," Procedia - Soc. Behav. Sci., vol. 181, pp. 423-430, 2015.

[44] B. A. Shawar., (2015). Evaluating Web Accessibility of Educational Websites. International Journal of Emerging Technologies in Learning, vol. 10, no. 4, pp. 4-10. https://doi. org/10.3991/ijet.v10i4.4518.

[45] D., Fok, M., Polgar, L., Shaw, \& J. W. Jutai, "Low vision assistive technology device usage and importance in daily occupations". Work, 39(1), 37-48, 2011. https://doi.org/10.32 $\underline{33 / \text { wor-2011-1149 }}$ 
[46] H., Hafiar, P., Subekti, \& A. R. Nugraha, "Internet Utilization by the Students with Visual Impairment Disabilities". International Journal of Emerging Technologies in Learning, vol. 14, no. 10, 2019. https://doi.org/10.3991/ijet. v14i10.10057.

[47] H. K. Kim, S. H. Han, J. Park, and J. Park, "The interaction experiences of visually impaired people with assistive technology: A case study of smartphones," Int. J. Ind. Ergon., vol. 55, pp. 22-33, 2016. https://doi.org/10.1016/j.ergon.2016.07.002.

[48] F. Yeh et al., "Learning by E-learning for visually impaired students: Opportunities or again marginalisation?” E-Learning Digit. Media, vol. 11, no. 1, pp. 439-448, 2014. https://doi.org/10.2304/elea.2012.9.4.439.

[49] S. Wicha, B. Sharp, Sureephong, P., Chakpitak, N. and Atkins, A. (2012). An animated dictionary for hearing-impaired students in Thailand. Journal of Research in Special Educational Needs, 12(4), 234-244. https://doi.org/10.1111/j.1471-3802.2012.01239.x

[50] N. Tye-Murray, S. Hale, B. Spehar, J. Myerson and M. S. Sommers, "Lipreading in School-Age Children: The Roles of Age, Hearing Status, and Cognitive Ability," Journal of Speech, Language, and Hearing Research, vol. 57, pp. 556-565, 2014. https://doi.org/ 10.1044/2013_JSLHR-H-12-0273.

[51] B., Baglama, M. Haksiz, \& H. Uzunboylu, "Technologies Used in Education of HearingImpaired Individuals" International Journal of Emerging Technologies in Learning, vol. 13, no. 09, pp. 53-63, 2018. https://doi.org/10.3991/ijet.v13i09.8303

[52] F. E. Kyle, R. Campbell, T. Mohammed, M. Coleman and M. MacSweeney, "Speechreading development in deaf and hearing children: introducing a new Test of Child Speechreading (ToCS)," Journal of Speech, Language, and Hearing Research, vol. 56, no.2, p. 416-426, 2013. https://doi.org/10.1044/1092-4388(2012/12-0039).

[53] L. Siegel, (2000). The educational and communication needs of deaf and hard of hearing children: A statement of principle on fundamental educational change. American Annals of the Deaf, 145(2), 63-78. https://doi.org/10.1353/aad.2012.0813.

[54] Gall, Gall and Borg (2003). Educational Research: An introduction Seventh Edition. Boston New York San Francisco: Pearson Education Inc.

[55] T C. Reeves and W. D. Aggen. Enhancing e-learning assessment and evaluation trategies. In Proceedings of ELEARN 2002 Vol. 2002 (1), 806811, 2002.

[56] M. Laabidi, M. Jemni, L. Jemni Ben Ayed, H. Ben Brahim, and A. Ben Jemaa, "Learning technologies for people with disabilities," J. King Saud Univ. - Comput. Inf. Sci., vol. 26, no. 1, pp. 29-45, 2014. https://doi.org/10.1016/j.jksuci.2013.10.005.

[57] P. Pocatilu, F. Alecu, and M. Vetrici, "Using Cloud Computing for E-learning Systems 2 Cloud Computing,” WSEAS Trans. Comput., vol. 9, no. 1, pp. 42-51, 2010.

[58] P. Pocatilu, F. Alecu, and M. Vetrici, "Measuring the efficiency of cloud computing for Elearning systems," WSEAS Trans. Comput., vol. 9, no. 1, pp. 42-51, 2010.

[59] C. S., Özgüç \& A. Cavkaytar, "Teacher use of instructional technology in a special education school for students with intellectual disabilities: A case study". Turkish Online Journal of Qualitative Inquiry, 5(1), 51-65, 2014. https://doi.org/10.17569/tojqi.14394.

[60] S. Flanagan, E. C. Bouck, ve Richardson, J. (2013). Middle school special education teachers' perceptions and use of assistive technology in literacy instruction. Assistive Technology. 25, 24-30. https://doi.org/10.1080/10400435.2012.682697.

[61] M. W. Ok, M. K. Kim, E. Y. Kang, \& B. R. Bryant, "How to find good apps an evaluation rubric for instructional apps for teaching students with learning disabilities." Intervention in School and Clinic, 2015. https://doi.org/10.1177/10534512155 89179.

[62] C. MacArthur, R.P. Ferretti, C.M. Okolo, ve Cavalier, A. R. (2001). Technology applications for students with literacy problems: A critical review. Elementary School Journal, 101, 273-301. https://doi.org/10.1086/499669. 
[63] P. Altass and S. Wiebe, "Re-imagining Education Policy and Practice in the Digital Era," J. Can. Assoc. Curric. Stud., vol. 15, no. 2, 2017.

[64] S. Astutik, \& B.K. Prahani, "The practicality and effectiveness of Collaborative Creativity Learning (CCL) model by using PhET simulation to increase students' scientific creativity" International Journal of Instruction, vol 11, no. 4, pp. 409-424, 2018. https://doi.org/10.12973/iji.2018.11426a

[65] Sunarti, T., Wasis, Madlazim, Suyidno, \& B.K. Prahani, "The effectiveness of CPI model to improve positive attitude toward science (PATS) for pre-service physics teacher Journal of Physics: Conference Series, 997(1), 012013, 2018. https://doi.org/10.1088/17426596/997/1/012013

[66] Sunarti, T., B.K. Prahani, Wasis, Madlazim, \& Suyidno, "Effectiveness of CPI (Construction, production, and implementation) teaching model to improve science literation for preservice physics teacher", Journal of Science Education, vol. 19, no. 1, pp. 73-89 2018. https://doi.org/10.1088/1742-6596/997/1/012013

[67] Suyidno, M. Nur, Yuanita, L., B.K. Prahani, \& B. Jatmiko, "Effectiveness of creative responsibility-based teaching (CRBT) model on basic physics learning to increase student's scientific creativity and responsibility”, Journal of Baltic Science Education, vol. 17, no. 1, pp. 136-151 2018.

[68] B. Jatmiko, B.K. Prahani, Munasir, P. Pandiangan, I. Wicaksono, N. Erlina, R. Althaf, \& Zainuddin, "The comparison of oripa teaching model and problem-based learning model effectiveness to improve critical thinking skills of pre-service physics teachers", Journal of Baltic Science Education, vol. 17, no. 2, pp. 300-319, 2018.

[69] F. A. Aksal, "Developing evaluative tool for online learning and teaching process", The Turkish Online Journal of Educational Technology, 10(3), 69-75, 2010.

[70] H.B. Gunduz, Digital divide in Turkish primary schools: Sakarya sample. TOJET: The Turkish Online Journal of Educational Technology, 9(1), 43-53, 2010.

[71] B Bahli. R. Saade. The impact of cognitive absorption on perceived usefulness and perceived Ease of use in on-line learning: an extension of the, technology acceptance model. Information and Management, 42, 2005. https://doi.org/10.1016/j.im.2003.12.013

[72] F. Jill, T. Dana, and B. Cyd. An exploratory study of online learning for professional development: Should club managers go the distance. Merlot Journal of Online Learning and Teaching, 4(3), 2008.

[73] K. Abdillahi Barreh and Z. Wati Abas, "A framework for mobile leanring for enhancing learnign in higher education,” Malaysian Online J. Educ. Technol., vol. 3, no. 3, pp. 1-9, 2015.

[74] R. Godwin-Jones, "Emerging technologies: mobile apps for language learning”. Language Learning and Technology, 15(2), 2-11, 2011.

[75] J. Ismaili, "Mobile learning as alternative to assistive technology devices for special needs students". Education and Information Technologies, vol. 22, no. 3, pp. 883-899, 2017. https://doi.org/10.1007/s10639-015-9462-9.

\section{Authors}

Assoc. Prof. Dr. Sri Joeda Andajani and Assoc. Prof. Dr. Asri Wijiastuti, senior lecturer and researcher at Universitas Negeri Surabaya, Surabaya, Indonesia.

Article submitted 2020-02-23. Resubmitted 2020-03-30. Final acceptance 2020-03-30. Final version published as submitted by the authors. 